\title{
Challenges Facing Entrepreneurship in Nigeria
}

\author{
Onyeka Uche Ofili ${ }^{1}$ \\ ${ }^{1}$ International School of Management, Paris, France \\ Correspondence: Onyeka Uche Ofili, International School of Management, Paris, France. E-mail: \\ ucheofili@gmail.com
}

Received: September 18, 2014

Accepted: October 23, 2014

Online Published: November 22, 2014

doi:10.5539/ijbm.v9n12p258

URL: http://dx.doi.org/10.5539/ijbm.v9n12p258

\begin{abstract}
Entrepreneurship is critical to the development of societies. Entrepreneurs however, cannot work in isolation; they need the right environment to thrive. The judicial system, the educational system, the financial system and general government policies should be such that encourage and promote entrepreneurship. Basic infrastructures such as power, water, and transport systems are necessary to boost entrepreneurship. This paper looks at the challenges facing entrepreneurship in Nigeria and recommend solutions to creating a better entrepreneurial society.
\end{abstract}

Keywords: entrepreneurship, Nigeria economy, institutional framework, infrastructure, entrepreneurs in developing countries, intellectual property protection

\section{Introduction}

An entrepreneur is a person, working within an existing organization or independently, who identifies a business opportunity within a given market and sets up an enterprise or subsidiary to take advantage of the opportunity (Gartner, 1988). He assumes the risks involved in pursuing the opportunity and also takes credit for the reward that may accrue from taking such risk. He however, ensures that the risk is well calculated before venturing (Timmons, 1978; Lynskey, 2002). Entrepreneurs by nature are innovative, creating new ideas and developing new business processes (Kirzner, 1973; Schumpeter, 1934; Bolton, 1986; Timmons, 1978). Entrepreneurs identify new markets; alter existing processes and ways of doing business in other to create something new, with improved value to the community within which the entrepreneur carries out his business (Hitt, Ireland, Camp \& Seton, 2001). The entrepreneur is quick to identify opportunities within a given market (Sull, 2004), having identified these opportunities he devices ways of curbing all potential and existing obstacles within the market environment (Kouriloff, 2000). Even though entrepreneurs derive pleasure in identifying opportunities to satisfy personal aspirations, they also seek to get commensurate financial reward for their efforts (Hisrich \& Peters, 1992; Boyd \& Gumpert, 1983). Entrepreneurs believe in taking calculated risks towards achieving their goals (Das \& Teng, 1997). Davids (1963) and Drahem (1972) both described entrepreneurs as founders of new businesses. Broekhaus (1980) opines that the individual or group of individuals should be the major owner of the business and not employed in another organization.

In essence entrepreneurs are characterized by the need to break new grounds and attain new heights (Komives, 1972; McClelland \& Winter, 1969). They possess strong value and personal discipline (Decarlo \& Lyons, 1979; Komives, 1972). They have strong self believe that they can control events around them (Broekhaus, 1980a; Broekhaus \& Nord, 1979; Liles, 1974). Individuals with these sorts of qualities can therefore contribute immensely to the growth of the economy if they are given the necessary platform to thrive. The onus is on the government to establish the right policy framework that can effectively spur the development of sustainable entrepreneurship. Entrepreneurs have the potential to transform the economic standing of a developing country. Landes (1998) put it that entrepreneurship can indeed promote poverty alleviation, encourage innovation, promote healthy competition and in the overall boost economic growth.

The rest of this paper will be organized as follows: Section two is a literature review of related topics; Section three is brief description of the methodology adopted for this research; Section four is on data description and analysis; This is followed by section five which is a recommendation of possible ways the government working closely with the private sector can create a better entrepreneurial society; and finally the paper reaches a conclusion in section six. 


\section{Literature Review}

Many literatures in the past have focused on defining who an entrepreneur is, the characteristics and traits of a typical entrepreneur. Not much work has been done in the area of understanding and differentiating the concept, characteristics and challenges of entrepreneurship in a developed world compared to a developing economy such as Nigeria (Lingelbach,Vina, \&Asel, 2005). It is only recently that some authors delved into understanding the concept of entrepreneurship in developing countries. Schimtz (1992) focused more on the constraints faced by small scale manufacturing firms in developing countries. Robinson (2002) considered entrepreneurship in developing countries with respect to microfinance banks. And the few literatures that delved into entrepreneurship in developing countries concentrated on describing the attributes of entrepreneurship in developing countries rather than researching and proffering ideas on the best framework within which entrepreneurs and policy makers can successfully thrive (Lingelbach, Vina \& Asel, 2005).

Naude, Szirmai \& Goedhuys (2011) pointed out that there is reasonable relationship between motivation, entrepreneurship and development. They further observed that the problem with developing countries is not the shortage of entrepreneurs but rather inadequate policy and institutional environment. They also opined that for innovation and invariably entrepreneurship to thrive government in developing countries should come to terms with the relevance of innovation in the development of their economies. Governments should implement innovation friendly reforms. This could include providing policies that will encourage the development of micro-finance banks, venture capital funds and other financial institutions designed to support small and medium size enterprises (SMEs).

Lingelbach, Vina \& Asel (2005) in their work noted that there is distinction between entrepreneurship in an emerging market and that of a developed economy. They observed that the degree of market efficiency influences the practice of entrepreneurship. They further observed that entrepreneurs situated in inefficient markets have to some extent be able to live above some of these inefficiencies. They basically identified three key factors that distinguish entrepreneurs situated in developing countries. They recognized that the opportunities for entrepreneurs in developing countries are much broader, giving entrepreneurs the chance to diversify their portfolio. Entrepreneurs can therefore, use some of their investments as hedge against risk that may be encountered in other industries. They argued that in as much as the opportunity in the developing market is broader the inherent risk in doing business in this sort of environment is much higher compared to developed economies. The last factor they recognized was human resources. They aligned with the views of Porter (1998) and Kantis\& Ishida (2002) that for a firm or an individual to be competitive the firm or the individual must acquire skills from trainings that are specific to the industry within which they operate. These firms can also acquire these requisite skills by collaborating and learning from other firms within the industry. One way of achieving this is by forming clusters (Porter, 1998). Clustering was identified as a powerful tool that can help in the development of entrepreneurs. The software cluster in India, the animation cluster in Philippines, and the wireless market cluster in China were all cited as cases in point.

Existing framework by Bhide (2000) on uncertainty, investment and profit was based mainly on the research conducted on entrepreneurship in the United States and other developed economies. It failed to substantially take into consideration the challenges of entrepreneurship in developing countries. Before now the general assumption was that entrepreneurship is the same the world over irrespective of whether it is in a developing or developed country. However, recent empirical research notably the World Business Environment Survey (WBES) and the Global Entrepreneurship Monitor (GEM) projects have revealed in more clear ways the challenges facing the formation of new businesses in developing countries. The GEM data is a compilation of responses from individuals from across the world on their perception of the concept of entrepreneurship and their involvement in entrepreneurial activities if at all (Reynolds et al., 2005).

Fasehun\&Bewayo (n.d) in their work recognized inadequate financial system as the main cause of very poor entrepreneurial performance in Nigeria. They argued that the country needs more micro-finance banks and that the existing micro-finance banks should be more efficiently managed. However, Bankole (2007) recognized that there are quite a number of factors that are responsible for the poor state of entrepreneurial growth in Nigeria. These include, access to market, poor infrastructure, lack of support from the relevant government agencies, lack of adequate finance, poor information dissemination and lack of access to the right technology. Oviawe (2010) argues that Nigerian youths can be better positioned for economic development and entrepreneurship through proper and focused education. He suggests that schools should integrate entrepreneurship as part of its curricula and should teach entrepreneurship at early age. She also suggests that entrepreneurs should be used as instructors and mentors in the school. 
This paper aims to examine the challenges facing entrepreneurs in Nigeria and the opportunities that are present in the market space despite these challenges. The paper will further recommend steps that can be taken to remedy the identified challenges. The paper recognizes that for entrepreneurs in Nigeria to become successful there is the need to first of all understand the challenges militating against entrepreneurship. It is after these challenges are identified that measures can be recommended to help take entrepreneurship to a higher level.

\section{Research Methodology}

This paper will adopt the qualitative research methodology. This will be a combination of observation, telephone and face-to-face interviews. Qualitative research approach is usually adopted when there are no existing theories or when existing theories fail to adequately explain a given occurrence, as is the case in this research.

In carrying out the research interviews this paper takes into cognizance the fact that individuals ascribe varying meanings and interpretation to specific issues depending on their current understanding and perception of that very issue. In other words individuals, in this case entrepreneurs may see issues that affect them based mainly on their social interaction within the environment they have found themselves (Merriam, 2002). This further implies that there may not necessarily be generally approved and permanent reality; rather there may be numerous understanding and interpretation of actuality based on individual perception.

So one of the major reasons behind qualitative research is to understand how entrepreneurs (this does not have to be only through interviews but could include group discussion, observations and so on) understand and interpret their social reality especially as it affects their businesses (Bryman, 1988). The interest of this research is therefore to basically ascertain what individual entrepreneur interpretations are at a given point in time and in a given context. The data collection technique used in this research is such that entails close interaction between the researcher and the research participants, thereby making the data collection very detailed, extensive and informative (Ritchie \& Lewis, 2003). Even though the researcher in qualitative research is the primary instrument for data collection and data analysis and is subject to bias this research strives to ensure that such biases are minimized as much as possible. This is achieved by trying as much as possible not to influence the opinion of the respondents but rather allowing each respondent to freely express his opinion in detail.

The interviews will be conducted in a semi-structured manner using the following methods; face-to-face interviews, telephone interviews and electronic-email interviews. This paper chose the electronic interview as one of the methods as it is not only gaining popularity but it is also quite convenient (Meho, 2006) especially when the respondents are very busy and situated in locations that are far apart.

\section{Data Presentation and Analysis}

The respondents to the interview are entrepreneurs and owners of businesses in various business sectors across different cities in Nigeria particularly Abuja and Lagos. They were notified of the interview either via email or Skype. For some of the respondents the interview was started and completed within a day, while for others it took several days due to their busy schedule. Some of the interviews were carried out via multiple email exchanges, while for some it was one or two emails and an in-depth telephone conversation, for a few it was an email followed by a face-to-face meeting. Skype was used with two of the respondents, as they were not in the country as at the time of the interview.

A total of 20 entrepreneurs were contacted but only 16 of them were available for the actual interview. The 4 potential participants that did not take part in the exercise did not actually decline the interview but mainly could not reach convenient time with the researcher due largely to their busy schedule. The research participants selected for this exercise have an average of over 10 years experience as entrepreneurs and come from very diverse business sectors. The sectors range from fashion to software design and development. Table 1 below shows the responses and remarks from the respondents when asked to express in their view the major challenges facing entrepreneurship in Nigeria. 
Table 1. Presentation of qualitative data

\begin{tabular}{|c|c|c|c|}
\hline Respondent & $\begin{array}{l}\text { Designation } \\
\text { Respondent }\end{array}$ & Summary of Remark & $\begin{array}{l}\text { Method } \\
\text { Interview }\end{array}$ \\
\hline 1 & Partner in a Law firm & $\begin{array}{l}\text { When this respondent was asked to share his views on the } \\
\text { challenges facing entrepreneurship in Nigeria, he listed the } \\
\text { following: } \\
\text { 1. The poor state of power and other key infrastructures. } \\
\text { 2. Skilled labor: From experience finding capable hands is always } \\
\text { very challenging in some cases you still end up wasting valuable } \\
\text { time doing tasks that could be easily delegated if your staff were } \\
\text { capable. } \\
\text { 3. Multiple Taxation: Most entrepreneurs are not very informed as } \\
\text { to what their tax obligations are or should be. } \\
\text { 4. Access to Capital: The requirements for accessing funds from } \\
\text { financial institutions and the exorbitant interest rates are a big } \\
\text { challenge for most entrepreneurs particularly the SME'S. } \\
\text { 5. Understanding \& Appreciation of Corporate Governance: Most } \\
\text { Entrepreneurs don't understand or appreciate the concept of } \\
\text { corporate governance. As a result most run their businesses as an } \\
\text { extension of themselves thereby limiting their growth potentials. } \\
\text { 6. Lack of continuity in Government policies: With every change in } \\
\text { government (and at times even in the same government) come } \\
\text { radical changes in policies. This has led many entrepreneurs to } \\
\text { adopt short-term business models. } \\
\text { The respondent is of the view that to fix the problems the failing } \\
\text { education systems has to be sorted out. Banks and lending houses } \\
\text { should cut their interest rates but even accessing such funds is } \\
\text { very difficult as the banks demand for unreasonable collateral. The } \\
\text { government should provide special funding alternatives for small } \\
\text { and medium scale enterprises. To fix the issue of frequent changes } \\
\text { in government policies, the government should put in place } \\
\text { long-term developmental plans that should not be subject to } \\
\text { changes in government regimes. }\end{array}$ & $\begin{array}{l}\text { Email and } \\
\text { Telephone } \\
\text { interview }\end{array}$ \\
\hline 2 & $\begin{array}{l}\text { Owner of a farm. } \\
\text { Also director and } \\
\text { shareholder in other } \\
\text { businesses }\end{array}$ & $\begin{array}{l}\text { This respondent is of the opinion that the following are the major } \\
\text { issues confronting entrepreneurship in Nigeria: } \\
\text { Lack of credit rating system, hence no risk management } \\
\text { infrastructure, therefore no serious fund lender. He asserts that } \\
\text { without proper financing entrepreneurship cannot thrive. } \\
\text { Also infrastructural challenges, including regulatory infrastructure } \\
\text { in his view is negating the growth of entrepreneurship. } \\
\text { He thinks there are too many frequent changes in regulatory } \\
\text { framework in Nigeria. And this in his view really hampers } \\
\text { entrepreneurship as entrepreneurship thrives under controlled risk } \\
\text { factors. When the goal posts keep on changing, serious } \\
\text { entrepreneurship is a mirage. } \\
\text { In summary he believes that these challenges can be classified as } \\
\text { lack of systems including strategy system, regulatory system, } \\
\text { financial system, and physical infrastructure system. } \\
\text { These problems in his opinion can be solved by doing the } \\
\text { following: } \\
\text { Build and develop the system pattern exactly the way they are } \\
\text { arranged above. Starting from strategy: what do we really want to } \\
\text { achieve in entrepreneur ship? How far do we want to go? The } \\
\text { strategy will determine all other things. Once we get the strategy, } \\
\text { we must institute regulatory framework. Entrepreneurship thrives } \\
\text { under free market enterprise and one of the fundamentals of free }\end{array}$ & Skype interview \\
\hline
\end{tabular}


market enterprise is right of ownership and limits and terms of engagement. He asserts that an entrepreneur is a like a criminal, only that he stretches the law to its limit without breaking it. Once the law becomes very elastic, there is no difference between a criminal and an entrepreneur anymore. These wrong activities may help a few individuals, but in the long run it kills genuine entrepreneurial spirit and destroys creativity. It is therefore imperative to have a robust and well-structured entrepreneurial system in place.

Owner of a food This respondent sees the following as the key factors militating retail chain against entrepreneurship in Nigeria:

The lack of a moral compass with very little role models in the society. People don't believe in hard work anymore they just want to make money but don't want to do the work.

The lack of infrastructure across board to support young businesses and startups.

The lack of qualified human resources due to the heavily decayed educational infrastructure in the country.

This respondent does not think that access to finance is a critical challenge.

In his view to solve the problems mentioned above, the following has to be done:

Creating a proper value system that has to start from the top. There has to be incentives for doing the right things

As concerning infrastructure, this can be changed by having the right and focused leadership. This will help improve education and other infrastructural deficits.

Founder/CEO

Telecoms company
Serial entrepreneur. Owns and manages multiple businesses
This respondent summarized the problems facing entrepreneurship in Nigeria as follows:

Finding staff with the right skill set and abilities is the number one issue. This is because you may have some good initiatives but not enough people to implement. Those that are capable are typically their own bosses or working for large corporations.

There is no good access to seed and project funding. Banks always want unrealistic amount of collateral and private equity or start up funding is limited.

Unreliable power/electricity is another factor he sees as working against real entrepreneurship in Nigeria.

And the last factor he identified is the low purchasing power of the majority of the market.

In his view to fix these problems government should endeavor to fix education and infrastructure. And also making investment funds available.

This respondent in his view summarized the problems confronting entrepreneurship in Nigeria as follows:

Start up Finance - The banks aren't supportive of start - ups because they always want a collateral unlike in the west where you can walk into a bank with a good business plan and get financing.

Human Capital - he thinks this one is unique to Nigerians (especially the ones living in Nigeria) because of their proud nature. Loyal employees are hard to find as per, everyone kind of wants to be their own boss (Not entirely a bad thing) but they don't want to put in the work and learn. I think this is one of the reasons behind so many failed small businesses.

Non Existent Regulatory Body or Structure to protect Intellectual
Email and face-to-face interview

Email interview Email interview 
Property - People tend to play their cards too close to their chest because of the fear that their ideas might be stolen by money bags who are preying on vulnerable entrepreneurs with little or no capital to bring their ideas to life and possibly enjoy First Mover Advantage while doing that.

High Cost of Business - Power and Public/mass transportation are not readily available. Using generator increases production costs/overheads generally. For someone in the import trade business, transportation costs are quite high here. It costs roughly two-thirds of the freight from China to Lagos to get the goods to Abuja from Lagos. This could have been minimized if we had cargo railways.

Economic Inequality - The disparity between the rich and poor in Nigeria is too much. The rich are extremely rich and the poor extremely poor. The middle class is very small in population and this has a negative effect on the purchasing power of the economy, which in turn discourages entrepreneurs.

Unhealthy Competition - This is mostly as a result of a lack of competent bodies to regulate quality and price. Some businesses sell inferior products at ridiculously low prices and there is little or nothing you can do to make them stop or prove to customers that products are inferior until after use. Some corrupt individuals recycle/round trip their ill-gotten wealth by importing products to sell at whatever price just to recoup the "cleansed wealth".

Too much reliance on imported goods and services - The local manufacturers cannot compete because of high costs as explained in 5 above. The extremely rich would rather give proven institutions contracts for services rather than encourage local entrepreneurs.

Fashion designer. Owner of a popular clothing line in Nigeria

Founder/CEO software company
When asked about the challenges facing entrepreneurship in Nigeria this respondent mentioned the following: irregular power supply (high cost of running generator), cost of rent/property; nonchalant attitude of staffand lack of funding. And even when you intend to hire very competent staff they are usually too expensive to afford.

Furthermore, he identified that loans are not easily accessible as the cost of borrowing is too prohibitive. With such loans it becomes difficult to pay back the loan and sustain the business.

$\mathrm{He}$ is of the view that these challenges can be solved by having well tailored government policies. Government policies should be such that support businesses. This could include tax breaks and reduction in the cost of borrowing.
In summary the challenges facing entrepreneurship in Nigeria in this respondent's view include the following:

Manpower issues - inadequate skill levels, wrong orientation and attitudes to work

No access to affordable credit facilities - bank interest rates are detrimental to small businesses especially those that don't trade in quick moving commodities

Unclear and conflicting government policies and general bureaucratic bottlenecks - multiple taxation, slow response time for government services, difficulties in accessing relevant and current information

And lastly he identified ubiquitous corruption and criminal levels of incompetence as also factors preventing the growth of entrepreneurship in Nigeria.
Email and Skype interview 
Co-owner/CEO of a
Location based
services company
This respondent believes these problems can be fixed if there will be improvement in the leadership of the country. He further suggests that entrepreneurs should learn to be more innovative and focused.

When this respondent was asked about his view concerning the challenges facing Nigeria, he mentioned the following as the key challenges:

Government policy: The policies of government are anti private sector. For a country that is striving with unemployment, it is expect that Government should relax its policies especially as regards tax and regulatory charges. This in his view will encourage the companies to hire more people. Government policies do not support the patronage on made in Nigerian goods. Government should put in place policies to support local content patronage.

Access to Capital: The high rate for acquiring capital to do business in Nigeria is very discouraging. In a country where lots of attention is on security and infrastructure development, it is expect that Government should have created a special incentive for specific sectors that need urgent intervention especially as it regards to capital to expand business.

Security: This is critical for every entrepreneur because without adequate security, the incentive to start or expand an existing business will fail.

Non-employable workforce: With the continuous decline in the standard of education in Nigeria, most employers are finding it difficult to hire qualified people to work for them.

One of the ways in his view that entrepreneurship can be promoted in Nigeria is by giving then incentives. Such incentives should not be generalized but should be industry specific. One of such incentives could be tax-breaks for startups; rebate for organizations that employ more than a certain number of staff.

Founder/CEO of an indigenous technology consulting firm in Nigeria

Owner/CEO of a photography and Arts start-up
This respondent when asked about the challenges facing entrepreneurship in Nigeria identified the following:

The first challenge in his view is the lack of enabling infrastructure; The next is the lack of access to risk capital to launch new venture; And lastly he identified negative perception of made in Nigeria products and services by Nigerian clients as a major setback for entrepreneurs.

The respondents is of the view that the above challenges can be fixed through the establishment of programs that will encourage public and private sector led infrastructure investment. There should be aggressive measures by the government to improve human capital development.

Also in his view the government needs to provide financial intervention to venture capital companies and private equity firms. And lastly there should be more awareness to encourage Nigerians to patronize made in Nigeria goods. And in turn Nigerian entrepreneurs should endeavor to produce more quality goods and services.

This respondent identified the following as the key challenges facing entrepreneurship in Nigeria:

First of all, most businesses are dependent on revenue from government, and due to corruption, bureaucracy and many other factors, it is tough to get anything done.

Secondly, Nigeria is simply a tough place to get anything done. You need a lot of money to properly setup any business as
Email and

Telephone

interview 
everything is paid for upfront, for example rent, furniture, vehicles, company registration, equipment etc. If you walk into a bank, the bank will $98 \%$ of the time never finance a startup even if you invest $70 \%$ of the cash required and you are merely looking for $30 \%$. Financiers especially banks lack clear understanding of entrepreneurs' requirements. Banks in Nigeria are not designed to take risks or finance small or medium businesses especially startups. They focus more on trade financing and invoice discounting.

Nigerian environment does not truly encourage start ups and entrepreneurship as there are no incubators, functional institutes of research, access to relevant data / information etc. No real tax holidays for businesses and indirect taxes from Local Government to Value Added Tax to Income taxes are not waived. Infrastructure remains a huge challenge especially electricity, the cost of diesel is quite high and contributes heavily to the cost of running a business. Access to skilled workforce is also another factor. Although gifted with a large population, the Nigerian workforce lacks exposure, experience and education to clearly hit the ground running for a business. This means that a business starting will need to invest in the training of their staff, which is another thing that is lacking in Nigeria (no access to good training programmes), which in turn increases business overhead costs significantly.

And lastly general efficiency of the system is a major militating factor. The Nigerian environment lacks serious efficiency from Government to the private sector. From policy flip-flops to the lack of implementation of policies; from so many loopholes in the system, which causes an un-even playing field to competitors. Also, the judicial system is gravely lagging behind in the disposition of trails and settling of disputes as it takes years to adjudicate on ligation matters.

This respondent is of the view that these challenges can be fixed through the reformation of government to become more effective and efficient. Also investment in education especially teaching entrepreneurship in schools will also go a long way in alleviating the challenges. Furthermore, providing incentives for venture capitals and banks will also help, as they will be better positioned to finance entrepreneurs. He also suggests that entrepreneurs also have a part to play, they should be more innovative and be willing to take more risks and they should also learn to be more patient. When asked about the challenges facing entrepreneurship in inefficiencies

[Unfavorable] Government Policy - creates uncertainty, increases risk, promotes corruption

Insecurity of Life and Property

He believes that capital income access is not peculiar to Nigeria. Furthermore, most entrepreneurs he has spoken to don't have finance [lack of finance] as top of their list. In his view finance is more of a top challenge for Large Scale Organizations than SMEs. 
Talent Acquisition.

And when asked to suggest ways he thinks this can be fixed he said: Government guarantees through Small and Medium Enterprises Development Agency of Nigeria (SMEDAN) for startups, crowd funding solutions and success stories of people getting very rich by investing in new ventures. He further opines that focus on shared and affordable infrastructure for entrepreneurs in high growth verticals should be implemented.

Owner/CEO of a maternity fashion brand
Owner/CEO of a training consulting company
This respondent is of the view that the problems facing entrepreneurship in Nigeria can be classified as follows:

Capital \& Funding: Getting capital is a tough task. Bank lending rates are too high and hard to acquire because of the stringent requirements such as tangible collateral.

She finds this problem a challenge because as a business owner, when I think of expansion and purchasing more goods in order to reduce on cost per order I can't achieve that desire. Its more frustrating to know that you have no where to get that kind of money from except to run to friends and family which is quite an informal money raising approach.

Lack of basic essentials and infrastructure: such as power, water and good roads. Most businesses require either of the fore mentioned to operate successfully. Without these infrastructures being made available, it creates a major additional expense to run the business. (For instance buying fuel to run a generator)

Lack of proper and adequate planning and research into the business of choice being operated. This makes you realize so many 'valleys' that you did not envisage when you started off.

She pointed out that in her case for example, she didn't know that a maternity fashion business though a niche market will result in her excluding much needed patronage from a vast market segment.

Hiring capable, qualified and trained staff is necessary but not done in practice as competent staff are hard to come by. This makes ones work extra hard as you always have to make up for sloppy staff and continuously bear the brunt of running the business alone with no productive input. If well-trained staff are employed, a lot of pressure will be taken off the CEO and invariably help the business grow.

This respondent argues that the number one issue militating against entrepreneurship in Nigeria is the lack of successful role models and mentors whose breakthroughs can be replicated. There is too much uncertainty in business. Why do programs like YouWIN (an innovative business plan competition aimed at job creation by encouraging and supporting aspiring entrepreneurial youth in Nigeria to develop and execute business ideas) fail so miserably? Why are there no major success stories out of Fate Foundation and Lagos Business School in spite of the huge sums invested in them? The second relates to how to make processes work for small businesses within Nigeria's chaotic business environment. We have an army of unemployed graduates yet the 1-man biz is still the norm. Access to capital is at the bottom of the list in his view. America and Europe have shown that capital alone is not enough.
Email and face-to-face interview 
Owner/CEO of an electronic payment platform

Owner/CEO of a software and firm
This respondent recommends that policy makers in Nigeria should learn from other successful countries and adapt their entrepreneurship strategies to suit Nigeria.

This respondent suggests that there are a number of factors working against entrepreneurship in Nigeria but the most important are namely:

Lack of a structured regulatory framework supporting and fostering entrepreneurship in the country;

Access to cheap capital is all but non-existent. There is no vibrant venture capital or investment houses geared to support entrepreneurs and start up;

Perhaps, a key factor is the dearth of skills in our environment this point alone is very critical.

This respondent suggests that one of the ways of promoting entrepreneurship is by having a robust and well-balanced intellectual property protection system. This in his view will really help to boost innovation, which will invariably promote entrepreneurship.

According to this respondent entrepreneurship in Nigeria is a huge burden especially as the government provides little or no incentive for the average businessman. Critical areas of disservice to a businessman can be clearly identified in the following sectors.

Government regulation and legislation around business registration, taxation, workers compensation and a host of other service are very outdated, cumbersome and riddled with corruption.

Absence of transparent and reliable basic services like the judiciary is a major bottleneck in local investment as an entrepreneur. The inadequate police services, irregular power infrastructure combined with total collapse of physical as well as social infrastructure largely serves as a disservice to entrepreneurs.

Most evidently absent is the willingness to incentivize entrepreneurs owing to the fiscal policies that are grossly unstable, unstructured tariffs including basic policy statements that are largely anti business (customs duties and the likes).

Warren Buffet once mentioned that he owes his success to his country the USA, because it created the enabling environment for him to flourish this includes the legal system, intellectual property protection, fair trade structure and a well-stimulated market. Nigeria needs to view business from the eyes of an entrepreneur to attract the right kind of investors and retain them. Today most of the investors in Nigeria are opportunistic and would repatriate their investments once they make the desired returns.

One of the ways this respondent thinks that the various problems identified above can be solved is by the government engaging entrepreneurs in policy formulation especially as it concerns business

\section{Email telephone} interview

A look at the responses from the research participants shows that there are some common factors affecting entrepreneurship in Nigeria. These include poor infrastructure including unreliable power supply, poor transport system, and weak judicial system. Almost all the respondents see the current state of infrastructure in the country as having a strong negative impact on entrepreneurship. Another common factor is poor education system, which in turn churns out people that are largely unemployable. In fact more than 50 percent of the respondents believe that lack of qualified and competent manpower is a major problem hampering entrepreneurship in Nigeria. Government policies and endemic corruption are another factor that most entrepreneurs see as negatively 
impacting entrepreneurial activities in Nigeria. They generally think that the policies formulated by the government are such that does not promote the growth of small and medium enterprises. This include the tax system, which some of them think is prohibitive and they cite instances of double taxation. Some argue that startups and small businesses should get some level of tax breaks and other incentives that will at least help their businesses especially in the early stages.

Even though only a few of the entrepreneurs see access to finance as a challenge others are of the view that finance would be easier if the entrepreneurs know how to come up with bankable business plans. Most entrepreneurs lack mentorship and guidance, they are mostly eager to setup their businesses without willing to learn from experienced entrepreneurs and businesses. This in their view is among the reasons some entrepreneurs fail in the early stages of their businesses as they do not carry out proper study of the business environment before venturing. However, the respondents still agree that even when you come up with a robust business plan the conditions for which one can obtain loan from the banks are too stringent. So, in their view while lack of easy access to finance may not be the number one issue it is also a problem.

Bankole (2007) basically corroborates some of the points highlighted during the interview process by identifying six major factors militating against entrepreneurship in Nigeria. He categorized these factors into a framework he referred to as 'MISFIT'. The M stands for access to market which he believes is lacking as most entrepreneurs in Nigeria lack basic knowledge about the market they intend to enter. The 'I' represents infrastructures, which he identifies as critical to the success of business. By infrastructure he refers to issues such as power supply, transport system etcetera. The ' $\mathrm{S}$ ' is for support agencies. He recognized that organizations that provide mentorship and guidance to entrepreneurs are too few and some of the ones that exit lack adequate knowledge on how to effectively mentor an entrepreneur. The ' $F$ ' stands for finance. This he sees as a major factor militating against entrepreneurship. The issue bothering on finance is not only about unavailability of finance or access to finance but also the mindset of some entrepreneurs. He recognized that even when the bankers committee in Nigeria some years ago came together and agreed to keep 10 percent of their profit aside to finance SMEs it was not effective. This was mainly due to the unwillingness of some entrepreneurs to let go of some equity in return for capital injection into their businesses. The businesses will rather go with debt financing as against equity financing. And meeting the conditions for debt financing is often too difficult for these businesses. Businesses are expected to provide collateral and other conditions, which they often cannot meet. The second ' $\mathrm{I}$ ' is quite close to the ' $\mathrm{M}$ '. He identified the relevance of information in the ability and willingness of an entrepreneur to want to venture. Access to information is vital for the entrepreneur to be able to research about the industry dynamics including opportunities and risks. Without such information it becomes more difficult for entrepreneurs to fine-tune their strategies. And lastly the ' $\mathrm{T}$ ' stands for technology. He argues that entrepreneurs in Nigeria lack access to the right technology that can ordinarily help make them more efficient, productive and invariably more competitive and profitable.

The findings in this research largely agree with Bankole's position but will add that there are two other critical areas that were not mentioned in his work and these include inadequate intellectual property right (IPR) protection and lack of robust entrepreneurial education. Issues bothering on ineffective protection of IPRs and lack of enforcement of contracts hamper the growth of entrepreneurs in any society. Nigeria has well articulated intellectual property (IP) laws and is signatory to key intellectual property related treaties and conventions such as World Intellectual Property Organization (WIPO) Copyright Treaty, WIPO Performances and Phonograms Treaty, Patent Cooperation Treaty, Patent Law Treaty, Convention Establishing the World Intellectual Property Organization, and Paris Convention for the Protection of Industrial Property (WIPO, 2011). However, the major problem in Nigeria is the enforcement of its intellectual property laws (Oyesina, 2010). Furthermore, capacity building is yet another factor militating against the prosperity of entrepreneurs in Nigeria. The country lacks qualified skilled labor. This is not unconnected with the failing educational system and almost non-existent vocational and technical schools where individuals can acquire skills in selected fields. All these have contributed adversely to the business concerns in Nigeria.

Having a robust intellectual property rights regime is important for the advancement of entrepreneurship in any society. There are mainly two major reasons why the protection of intellectual property right is important. The first is for the encouragement and promotion of innovation by granting the intellectual property right holders exclusive rights to use and sell their newly developed technologies, goods and services. The second is to ensure that relevant knowledge is continuously made available for public consumption and interest. It is important that the government balances these two main reasons by ensuring that there is neither over protection of IPR as this could limit the social benefits of innovation nor under protection, as this will discourage innovation. Contract 
enforcement should also be taken seriously as lack of it erases business confidence which is detrimental to entrepreneurial development.

The Nigerian public in recent years resort more to the court system to seek redress to contract issues. However, they often get disappointed as they do not get fair and impartial judgments. The World Bank's publication on "Doing Business 2014" surveyed 189 countries across the world. Out of this number Nigeria ranked 136 on the enforcement of contracts. The country moved up by 2 positions as it was ranked 138 under the same category in a similar survey conducted in 2013. The report further stated that contract enforcement required 40 procedures and an average of 477 days. The average legal cost of pursuing the contract cases averaged 92 percent of the total value of the contact. On the other hand contract enforcement in Organization for The Economic Co-operation and Development (OECD) countries required an average of 31 procedures, and spans an average of 529 days at an average cost of 21 percent of the total cost of the contract. Nigeria is worse than the sub-Sahara African average which requires an average of 39 procedures over an average of 652 days, and 51.1 percent of total contract sum (World Bank, 2014).

Different scholars such as North (1981) and Machlup (1958) believe that there is reasonable correlation between intellectual property system and the economic development of a nation. They argue that having a robust intellectual property protection system is necessary for sustainable economic development. They suggest that such a system will promote innovation as IPR owners will be encouraged to research more and those who do not have any IPRs will be encouraged to work harder and come up with new innovations knowing that their efforts will be adequately rewarded and protected. Since ideas and information are necessary for the development of any society the creators of these ideas have to be given the right incentives to continue to produce ideas that are relevant for the benefit of the entire community (Asia-Pacific Economic Cooperation, 2006).

In other to continue to encourage creativity and innovation governments establish IP laws and enforcement policies; granting IP rights such as patents and copyrights. Patents and copyrights and indeed any other intellectual property right permit the owner limited time to enjoy monopoly over the property. The owner of the right may also decide to license his IPR to others for a consideration or he may decide to sell it to a third party outright. As mentioned earlier the Nigeria judicial system must begin to adequately enforce intellectual property rights protection and indeed other contracts if the country intends to boost internal and external investors' confidence. Enforcing laws will encourage entrepreneurs to invest their time and resources in Nigeria and it will also encourage foreigners to want to invest in Nigeria. Adams (2010) suggests that strong IPR protection has positive effect on foreign direct investment (FDI), which invariably has positive effect on the economic growth of a nation.

Some entrepreneurs may be able to take advantage and benefit from FDI as some foreigners may feel more comfortable investing in start-ups if they know the company has IPR and that these IPRs are well protected through adequate and robust government policies. So in essence having a robust IP system will not only encourage people to innovate and start up new businesses but will help these start ups to raise capital. This has a similar effect as the enforcement of contracts agreements between two or more parties. Present reports show that contract enforcement in Nigeria is still very poor. Banks and other financial institutions shy away from lending money to startups, as it is very difficult to enforce the contracts. The United States Department of States reported that, "In at least three prominent cases between 2008 and 2010, local companies or government officials manipulated the judicial system or law enforcement agencies to exert undue pressure on international companies for commercial or personal advantage" (US Department of State, March 2011).

\section{Recommendations}

Zhang (2005) identified that India's success so far in driving entrepreneurship came about through various attempts. These attempts can be classified under the following broad headings: removal of barriers imposed by government policies and inefficiencies towards starting up new businesses; recognizing that finance is critical for entrepreneurship and making same available and finally promoting entrepreneurial education and nurturing in the school system. Nigeria government can take a cue from this and adapt it where necessary to suite the Nigeria business, political and social environment. The government can start by reducing over regulation of some selected industries. It can give deliberate tax breaks in some industries to encourage new businesses to get into those industries. An example of this is in India where the government deliberately granted tax holidays to start-ups. This subsequently caused a huge growth in Bangalore and Hyderabad, as both cities became major hubs for information technology companies (Zhang, 2005).

In the current financial structure in Nigeria it is much easier for established businesses to get funding from banks to finance new ventures than it is for new entrepreneurs to raise capital. It is therefore, imperative that the 
government puts in place mechanisms for raising funds for new businesses. In 2005 the government established the micro-finance policy. One of the key objectives of the policy is to "enhance service delivery (provision of financial support) by micro-finance institutions to micro, small and medium entrepreneurs" (Central Bank of Nigeria, 2005). It is intended that the micro-finance banks will "provide diversified, affordable and dependable financial services to active poor, in a timely and competitive manner that would enable them to undertake and deliver long-term, sustainable entrepreneurial activities" (Central bank of Nigeria, 2005). The government should therefore ensure that these micro-finance banks have reasonable capital base and that they provide the services they are setup to render. The government can also setup special bodies or work with the Small and Medium Enterprise Development Agency of Nigeria (SMEDAN) to provide special funds for start-ups. The government can ensure that organizations/individuals that receive these special funds are able to pay back by adopting the services of organizations such as the Enterprise Development Centre (EDC). The EDC has adopted psychometric testing to predict credit risk. EDC recognized that it is difficult for most start-ups to present all the securities and collateral required to obtain a loan from a bank. To get around this, the EDC adopted Harvard University's Entrepreneurial Finance Lab initiative of using psychometric testing to predict credit risk (Wylie, 2011).

Athreye (2011) recognized that despite the adverse market environment India businesses are confronted with, such as: over regulation, high cost of doing business, weak enforcement of property rights, poor capital market, entrepreneurs are able to survive. He pointed out that the India software industries found a way around these obstacles. India software entrepreneurs adopted models that helped them capitalize on the cheap and abundant skilled software developers. He however, noted that the success recorded by this industry was boosted by improvement in institutional infrastructure such as improvement in labor market reform, better access to finance and reasonable improvement in contract enforcement and IP rights protection. He further made it clear that these positive changes in the institutional environment was not as a result of government taking the lead through focused policies but rather the initiatives came about through institutional entrepreneurship. The import of this is that the private sector was in the forefront of making the business environment conducive for business operation.

Nigeria universities churn out huge amount of graduates yearly but only a small percentage of these students get employed after leaving school. It is in fact estimated that the unemployment rate of university graduates in Nigeria is around 25 percent (Dabalen, Oni, \& Adekola, 2000). To curb this problem, engage the graduates and promote economic growth the country has to imbibe entrepreneurship in its academic system. Schools should incorporate entrepreneurship into their curriculum. For instance Li, Zhang \& Matlay (2003) identified that entrepreneurial education is inculcated into the curriculum of some business schools in China. Shanmugaratnam (2004) discovered that entrepreneurial education is implemented in the National University of Singapore (NUS). This should be made as a policy by the government and the policy should be such that encourage existing entrepreneurs to help the schools define, deliver and evaluate their training programs. Professional associations such as computer society of Nigeria, Nigeria society of engineers, institute of chartered accountants of Nigeria should be involved in the program and other non-for-profit organizations should also play a role. The government working in collaboration with the organized private sector should from time to time evaluate the sectors that have added more significant value to the country's GDP through entrepreneurship and educate and nurture students to step up businesses in those sectors.

In order for Nigeria to encourage entrepreneurship it should have a solid IPR strategy. In setting out this strategy it must do so by balancing the interest of the public and the interest of the IPR owner. Joseph Story in [Folsom V Marsh, 9F. (as 342 (1841)] ruled "we must often, in deciding questions of this sort, look to the nature and objects of the selections made, the quantity and value of the materials used, and the degree in which the use may prejudice the sale, or diminish the profits, or supersede the object of the original work." The strategy should be such that while encouraging innovation and promoting entrepreneurship does not work against the social interest and benefit of the rest of the society (Khan, 2002). Nigeria already has the necessary laws concerning intellectual property protection what is lacking as pointed out earlier is the proper implementation of these laws. The government should instruct the relevant law enforcement agencies to ensure strict enforcement of the IPR laws. The government should perhaps reconsider harmonizing the different agencies responsible for carrying out different aspects of intellectual property related activities. These agencies include National Office for technology Acquisition and Promotion (NOTAP) an agency under the Federal Ministry of Science and Technology: responsible for registering technology transfer agreements, promotion of intellectual property rights, commercialization of research outcomes and inventions and the provision of patent information and documentation. Nigeria Copyright Commission (NCC) an agency under the Federal Ministry of Justice has the mandate to establish the appropriate enabling environment for the protection of copyright and also to ensure the 
proper enforcement of all copyright works protected under the laws of the Federal Republic of Nigeria. The Industrial Property Office (IPO) an agency under the Federal Ministry of Commerce and Industry is responsible for the registration of Trademarks, Patents and Designs (www.wipo.int). The government should as a matter of urgency revisit the subject of the Nigerian Intellectual Property Commission (NIPCOM), which it had established in 2009 to administer intellectual property matters in the country (Ebhuomhan, 2009). This will ensure that all intellectual property matters are handled within a single organization. It will help for easy administration of intellectual property matters and make it easier for the public to make enquiries and register their intellectual properties. Having such an efficient and effective intellectual property office will greatly encourage innovation and invariably entrepreneurship. The public should be enlightened on the benefits of registering their intellectual property. And the process of carrying out such registration should be made simpler and easier. It should also be made available online for those who will prefer to register their trademarks, patents and so on online. And lastly the Corporate Affairs Commission (agency responsible for registering new businesses) should reduce the number of days it takes to register a new company by reducing the number of steps and taking the entire process online. The online platform should also allow companies to be able to do their annual return fillings and general enquiries online.

\section{Conclusion}

To have a truly entrepreneurial system in Nigeria the private sector/business owners will need to work with the government to define what is suitable. Entrepreneurs in Nigeria should not only see the challenges, which by no means should not be discounted, but should also learn to take advantage of the opportunities. Like the India example cited above, Nigerian entrepreneurs can find smart ways of surviving within the present economic structure of the country while still collaborating with the government to improve the system. They can indeed help to build the desired strong and conducive business environment. Furthermore, entrepreneurs should see the importance of learning under established entrepreneurs and businesses. They should ensure they have a firm understanding of the business environment before venturing. They should desire and embrace sound mentoring. They should be more innovative and understand that they have to nurture their ideas until it becomes profitable and this may take some time.

The government on the other hand should come to terms with the fact that one of the ways of growing the economy is to promote entrepreneurship. To achieve this it should build a society that promotes and encourages entrepreneurship. The private sector cannot realize and solely build a truly entrepreneurial society without recourse to the government. The government should build the right institutional environment such as reforming the educational system and the judicial system. The educational system should incorporate entrepreneurial teaching and nurturing while the judicial system should be such that is responsive to IPR protection. Furthermore the financial institutions should adequately incorporate and set aside adequate funding for sponsoring of new innovative enterprises. It is also important that key infrastructures including power, transport and water are fixed and made readily available.

\section{References}

Adams, S. (2010). Intellectual Property Rights, Investment Climate and FDI in Developing Countries. International Business Research, 3(3). http://dx.doi.org/10.5539/ibr.v3n3p201

Alford, W. P. (1995). To steal a book is an elegant offence: Intellectual Property Law in Chinese Civilization. Stanford, California: Stanford University Press.

Allison, J. R., \& Lin, L. (1999). The evolution of Chinese attitudes towards property rights invention and discovery, University of Pennsylvania. Journal of International Economic Law, 20, 735. http://dx.doi.org/10.2139/ssrn.222539

Athreye, S. (2011). Overcoming Adversity in Entrepreneurship-led Growth. Evidence from the India software sector. In Entrepreneurship, innovation, and Economic Development. Chapter 11. http://dx.doi.org/10.1093/acprof:oso/9780199596515.003.0011

Baldus, O. (2010). The 'One Size Fit All' problem of patent systems. Journal of Intellectual Property Law and Practice, 5(10), 724-729. http://dx.doi.org/10.1093/jiplp/jpq099

Bankole, P. (2011). The Entrepreneurship Challenge in Nigeria. Retrieved August 27, 2011 from http://knowledge. wharton.upenn.edu/article.cfm?articleid=1675

Bolton, W. K. (1986). The university sector and technology transfer. In Wayne S. Brown and Roy Rothwell (Eds.), Entrepreneurship \& Technology: World experiences and policies. Harlow: Longman. 
Boyd, D. P., \& Gumpert, D. E. (1983). Coping with entrepreneurial stress [Electronic version]. Harvard Business Review, 61, 44-64. Retrieved from http://hbr.org

Brockhaus, R. H. (1980). Risk taking propensity of entrepreneurs. Academy of Management Journal, 23(3), 509520. http://dx.doi.org/10.2307/255515

Brockhaus, R. H., \& Nord, W. R. (1979). An exploration of factors affecting the entrepreneurial decision: Personal characteristics vs. environmental conditions. Acad. Manage Proc., (1), 364-368. http://dx.doi.org/10.5465/AMBPP.1979.4977621

Bryman, A. (1988). Quantity and quality in social research. London, Boston: Unwin Hyman Publications.

Central Bank of Nigeria. (2005). Micro-Finance Policy, regulatory and supervisory framework for Nigeria. Retrieved from http://www.cenbank.org/out/Publications/guidelines/dfd/2006/microfinance\%20policy.pdf

Colvin, G. (2011). Corruption: The biggest threat to developing economies. Retrieved from http://rightwaysrichard.blogspot.com/2011/04/corruption-biggest-threat-to-developing.html

Dabalen, A., Oni, B., \& Adekola, O. A. (2000). Labor Market Prospects of University Graduates in Nigeria. Retrieved from http://www.valuefronteiraonline.com/public_upload/file/edu1.pdf

Davids, L. E. (1963). Characteristics of small business founders in Texas and Georgia. Athens, Ga.: Bureau of Business Research, University of Georgia.

Das, T. K., \& Teng, B. (1997). Time and entrepreneurial risk behavior. Entrepreneurship Theory and Practice, 22(2), 69-88. Retrieved from http://aux.zicklin.baruch.cuny.edu/tkdas/publications/das-teng_etp97_timeentriskbeh_69-88.pdf

DeCarlo, J. F., \& Lyons, P. R. (1979). A Comparison of Selected Personal Characteristics of Minority and Non-Minority Female Entrepreneurs. In Academy of Management Proceedings (No. 1, pp. 369-373). Academy of Management. Retrieved from http://proceedings.aom.org/content/1979/1/369.full.pdf

Draheim, K. P. (1972). Factors influencing the rate of formation of technical companies. In A. C. Cooper \& J. L. Komives (Eds.), Technical entrepreneurship: A Symposium. Milwaukee: Center for venture Management (pp. 3-27).

Drahos, P., \& Braithwaite, J. (2002). Information Feudalism: Who owns the knowledge economy? The New Press, New York, NY.

Ebhuomhan, S. (2009). FG Replaces NCC With NIPCOM. Retrieved fromhttp://www.thenigeriabusiness.com/eco264.html

Fasehun, O., \& Bewayo, E. (n.d). Promoting Entrepreneurship in Nigeria through Microfinance. Retrieved from http://whitman.syr.edu/ABP/Conference/Papers/Promoting\%20Entrepreneurship\%20in\%20Nigeria\%20thro ugh\%20Microfinance.pdf

Gartner, W. B. (1988). Who Is an Entrepreneur? Is the Wrong Question. American Journal of Small Business 12(4), 11-32. Retrieved from http://business2.fiu.edu/1660397/www/Session\%202\%20Readings/Gartner_1988_All.pdf

Hisrich, R., \& Peters, M. (1992). Entrepreneurship: Starting, developing, and managing a new enterprise. Boston: Irwin.

Hitt, M., Ireland, D., Camp, S., \& Sexton, D. (2001). Strategic entrepreneurship: entrepreneurial strategies for wealth creation. Strategic Management Journal, 22(6-7), 479-491. http://dx.doi.org/10.1002/smj.196

Khan, B. Z. (2002). Intellectual Property and Economic Development: Lessons from America and European History. Retrieved from http://www.iprcommission.org/papers/pdfs/study_papers/sp1a_khan_study.pdf

Kirzner, I. M. (1973). Competition and entrepreneurship. Chicago: The University of Chicago Press.

Komives, J. L. (1972). A preliminary study of the personal values of high technology entrepreneurs. In A. C. Cooper \& J. L. Komives (Eds.), Technical entrepreneurship: A Symposium. Milwaukee: Center for venture Management (pp. 231-242).

Kouriloff, M. (2000). Exploring Perceptions of A Priori Barriers to Entrepreneurship: A Multidisciplinary Approach. Entrepreneurship: Theory and Practice. Baylor University. 2000. Retrieved October 18, 2014 from HighBeam Research: http://www.highbeam.com/doc/1G1-74524633.html 
Li, J., Zhang, Y., \& Matlay, H. (2003). Entrepreneurship Education in China. Education +Training, 45(8/9), 495-505. Retrieved from http://www.emeraldinsight.com/doi/abs/10.1108/00400910310508883

Liles, P. (1974). Who are the entrepreneurs? MI, USA. Graduate School of Business Administration, Michigan State University.

Lingelbach, D., Vina, L. \&Asel, P. (2005). What's distinctive about growth-oriented entrepreneurship in developing countries? UTSA College of Business Center for Global Entrepreneurship Working Paper No. 1. http://dx.doi.org/10.2139/ssrn.742605

Lynskey, M. J., \& Yonekura, S. (2002). Entrepreneurship and Organization-The Role of the Entrepreneur in Organizational Innovation. Oxford: Oxford University Press.

Machlup, F. (1958). An Economic Review of the Patent System. Wash., DC, US Govt Printing Office, 1958, p. 80

Mansfield, E. (1991). Unathourized use of Intellectual Property: Effects of investment, technology transfer, and innovation. In Wallerstein, Mogee and Schoen (Eds.), Global Dimensions of Intellectual Property Rights in Science and Technology. National Academy Press.

Mansfield, E. (1994). Intellectual property Protection: FDI and technology Transfer. IFC Discussion paper No. 9, World Bank.

McCalman, P. (1999). Reaping what you sow: an empirical analysis of international patent harmonization. Journal of International Economics, 55(1), 161-186. http://dx.doi.org/10.1016/S0022-1996(01)00091-5

McClelland, D., \& Winter, D. G. (1969). Motivating economic achievement. New York: Free Press.

Meho, L. I. (2006). E-mail interviewing in qualitative research: A methodological discussion. Journal of the American Society for Information Science and Technology, 57(10), 1284-1295. http://dx.doi.org/10.1002/asi.20416

Merriam, S. B. (2002). Qualitative research in practice: Examples for discussion and analysis. San Francisco: Jossey-Bass.

National Office for Technology Acquisition and Promotion. (2011). Retrieved from http://www.notap.gov.ng/

Nigeria Communications Commission. (2011). Operator Data. Retrieved from http://www.ncc.gov.ng/index.php?option=com_content\&view=article\&id=70\&Itemid=76

North, D. C. (1981). Structure and Change in Economic History. New York: Norton.

Oviawe, J. I. (2010). Repositioning Nigerian Youths for Economic Empowerment through Entrepreneurship Education. European Journal of Educational Studies, 2(2). Retrieved from http://ozelacademy.com/ejes.htm

Oyesina, T. (2010). Enforcing copyrights law in Nigeria. Daily Tribune Newspaper. Retrieved from http://www.tribune.com.ng/index.php/tribune-law/9363-enforcing-copyrights-law-in-nigeria

Porter, M. E. (1985). Competitive Strategy: Techniques for Analyzing Industries and Competitors. New York, NY: Free Press

Robinson, M. (2001-2). The Microfinance Revolution. Washington: World Bank.

Reynolds, P., Bosma, N., Autio, E., Hunt, S., De Bono, N., Servais, I., Lopez-Garcia, P., \& Chin, N. (2005). Global entrepreneurship monitor: data collection design and implementation, 1998-2003. Small Business Economics, 24(3), 205-231. http://dx.doi.org/10.1007/s11187-005-1980-1

Ritchie, J., \& Lewis, J. (2003). Qualitative Research Practice: A Guide for Social Science Students and Researchers. London, UK: Sage Publications.

Schmitz, H. (1992). Growth Constraints on Small-scale Manufacturing in Developing Countries: A Critical Review. World Development, 10(6), 429-450. http://dx.doi.org/10.1016/0305-750X(82)90001-8

Schumpeter, J. A. (1934). The Theory of Economic Development. Cambridge, Mass.: Harvard University Press.

Shanmugaratnam, T. (2004). Entrepreneurship Education Asia 2004. Key note address at the inaugural roundtable on entrepreneurship education Asia 2004 .National University of Singapore. 29 July. Retrieved from http://www.moe.gov.sg/media/speeches/2004/sp20040729.htm

Sull, D. N. (2004). Disciplined entrepreneurship. MIT Sloan Management Review, 46(1), 71-77. Retrieved from http://sloanreview.mit.edu/ 
US Department of State. (2011). 2011 Investment Climate Statement-Nigeria. Retrieved from http://www.state.gov/e/eb/rls/othr/ics/2011/157337.htm

World Intellectual Property Organization. (2011). Nigeria. Retrieved from $\mathrm{http}: / / \mathrm{www}$. wipo.int/wipolex/en/profile.jsp?code=NG

World Economic Forum. (2011). Global Competitiveness Report 2011-2012. Retrieved from http://www3.weforum.org/docs/WEF_GCR_Report_2011-12.pdf

World Bank. (2014). Doing Business Report 2014: Ease of Doing Business in Nigeria. Retrieved from http://www.doingbusiness.org/data/exploreeconomies/nigeria/

Wylie, I. (2011). Enterprising lessons for entrepreneurs. Financial Times. Retrieved fromhttp://www.ft.com/intl/cms/s/2/3556783a-7263-11e0-96bf-00144feabdc0.html\#axzz1YHd2RMaK

Zhang, L. (2005). Entrepreneurship Education within India's Higher Education System. Retrieved from http://www.asianscholarship.org/asf/ejourn/articles/zhang_l.pdf

\section{Copyrights}

Copyright for this article is retained by the author(s), with first publication rights granted to the journal.

This is an open-access article distributed under the terms and conditions of the Creative Commons Attribution license (http://creativecommons.org/licenses/by/3.0/). 